\section{Chipped Pine Logs: A Potential Substrate for Greenhouse and Nursery Crops}

\author{
Robert D. Wright ${ }^{1}$ and Jake F. Browder ${ }^{2}$ \\ Department of Horticulture, Virginia Tech, Blacksburg, VA 24061
}

Additional index words. container media, pine bark, pine chips

\begin{abstract}
Due to uncertainties of future supplies of pine bark (PB) and peatmoss, ground Pinus taeda logs [pine chips (PC)] were compared to ground PB as a potential container substrate for japanese holly (Ilex crenata Thunb. 'Chesapeake'), azalea (Rhododendron obtusum Planch. 'Karen'), and marigold (Tagetes erecta Big. 'Inca Gold'). Plants were potted in 2.8-L plastic containers 8 Apr. 2004 with either $100 \%$ PC, $100 \%$ PB, or $75 \%$ PC:25\% PB (v/v), and glasshouse grown 8 weeks for marigold and 13 weeks for holly and azalea. Plant dry weights were higher for marigold grown in $100 \%$ PB compared to $100 \%$ PC but not different from plants grown in 75\% PC:25\% PB. Plant dry weights of azalea were higher in $100 \%$ pine bark than both substrates containing chips. There was no difference in shoot dry weight for japanese holly between the three substrates. Root dry weight was higher for $75 \%$ PC: $25 \%$ PB than for $100 \% \mathrm{~PB}$, but root weight of $100 \%$ $\mathrm{PB}$ and $100 \%$ PC was the same. The percent air space for the $\mathrm{PC}$ was higher than the PB substrate but container capacity and available water was not different for the three substrates. Substrate solution electrical conductivity (EC) for PC, was lower than that of $\mathrm{PB}$, possibly due to greater leaching with the more porous $\mathrm{PC}$ and nutrient retention by the PC. These factors could account for the cases where larger plants developed with the PB substrate. Nutrient analysis of the substrate solution indicated that there are no toxic nutrient levels associated with PC. The $\mathrm{pH}$ of $\mathrm{PC}$ is also acceptable for plant culture. As well, there was no apparent shrinkage due to decomposition during the course of this short-term experiment. Pine chips, therefore, offer potential as a container substrate for greenhouse and nursery crops.
\end{abstract}

Peatmoss and softwood bark have provided the primary base for most greenhouse and nursery substrates over the last 30 years. These materials are excellent substrates but their future availability is uncertain. The environmental concerns of mining peatmoss and the increasing costs of this substrate are factors that could limit availability and use. As well, the availability of softwood bark of consistent quality is often a problem due to the variety of methods used to harvest, process, and store bark. In addition, potential movement of the lumber and paper industry to other countries will likely limit the supply of softwood bark. Many studies have investigated the use of numerous industrial and agriculture waste such as animal wastes (Tyler et al., 1993b), cotton gin waste(Owings, 1993), wood by-products (Lunt and Clark, 1959; Chong and Lumis, 2000), municipal leaf and sewage sludge (Bugbee et al., 1991; Rosen et al., 1993) rice hulls (Dueitt et al., 1993), and residential refuse (Kahtz and Gawel, 2004) as substitutes for bark and peatmoss. Most of these alternative substrate components show promise in that they are nontoxic to plants and can be successfully used to amend conventional substrates. However, regional availability and a limited supply of uniform and consistent quality product reduces their widespread usage.

Therefore, there is a need for a substrate that is of consistent quality, renewable, economically priced and of unlimited supply. Since two

Received for publication 2 Nov. 2004. Accepted for publication 27 Dec. 2004.

${ }^{1}$ Professor:

${ }^{2}$ Graduate student. byproducts of the forestry industry, pine bark (Porkorny and Wetzstein, 1984) and sawdust (Ehret et al., 1998) have been shown to be acceptable components of container substrates, whole tree logs processed into a container substrate may be a suitable and economical alternative to conventional substrates. Trees are renewable, reasonably priced, and widespread geographically. The purpose of this work was to investigate the potential of producing a container substrate from whole tree logs suitable for greenhouse and nursery crops.

\section{Materials and Methods}

Wood chips were produced by grinding a $17 \mathrm{~m}$ long $\times 25 \mathrm{~cm}$ basal diameter loblolly pine (Pinus taeda L.) $\log$ (including the bark) with a Morbark Chipper (Winn, Mich.) operated at Wood Preservers, Inc, Warsaw, Va. These chips are routinely produced by the forestry industry and used for paper manufacturing or as an energy source at power plants. Chip size was reduced further with a Crary Bear Cat chipper (West Fargo, N.D.) to a particle size suitable for a container substrate (Table 1). Ground, aged loblolly PB (conventional PB substrate) was used as a second substrate and blended with PC for a third substrate. Three plant species, japanese holly (Ilex crenata Thunb. 'Chesapeake'), azalea (Rhododendron obtusum Planch. 'Karen'), and marigold (Tagetes erecta Big. 'Inca Gold'), were potted on 8 Apr. 2004 in 2.8-L plastic containers with the following substrates: $100 \% \mathrm{~PB}, 100 \% \mathrm{PC}$, and 75\% PC: $25 \%$ PB. Osmocote Plus (O.M. Scott Horticulture Products, Marysville, Ohio) at 7.5 $\mathrm{kg} \cdot \mathrm{m}^{-3}$ for holly and marigold and $5 \mathrm{~kg} \cdot \mathrm{m}^{-3}$ for azalea were preplant incorporated into each substrate. Initially the substrate solution EC levels of the PC treatments were lower than $\mathrm{PB}$, therefore $\mathrm{PC}$ treatments received occasional fertilizer applications in the irrigation water (300 ppm N from $\mathrm{NH}_{4} \mathrm{NO}_{3} 45 \mathrm{ppm} \mathrm{P}$ from $\mathrm{H}_{3} \mathrm{PO}_{4}$, and $150 \mathrm{ppm} \mathrm{K}$ from $\mathrm{KCl}$ ) to maintain the PC EC readings near those of the $\mathrm{PB}$. The experimental design was completely randomized with six plants per treatment. On 14Apr., substrate solutions were extracted from 6 unfertilized fallow containers with either $100 \%$ PB or $100 \%$ PC using the pourthrough method (Wright, 1986) and then, on 22 Apr., substrate solutions were extracted from 6 containers for each of the three substrates that had been planted and fertilized. Substrate solution nutrient concentrations using ICAP analysis as well as $\mathrm{pH}$ and $\mathrm{EC}$ were determined. EC and $\mathrm{pH}$ readings were taken periodically during the experimental period.

On 1 June 2004 marigold shoots were severed at the substrate surface, dried at 70 ${ }^{\circ} \mathrm{C}$ for $4 \mathrm{~d}$ and weighed. On 12 July azalea and holly shoots were severed at the substrate surface, dried at $70{ }^{\circ} \mathrm{C}$ for $3 \mathrm{~d}$ and weighed. Holly roots were separated from the substrate, dried, and weighed. Due to the very thin roots of azaleas and marigolds separating roots from substrate resulted in loosing a large percentage of the roots, thus no root weights of azalea and marigold were taken.

Physical properties of each substrate were determined according to Tyler et al. (1993a) on four replicate samples removed from four azalea containers at the end of the experiment. Cation exchange capacity (CEC) was determined by A \& L Eastern Agricultural Laboratories, Richmond, Va., according to AOAC Official Method 973.09, CEC for peat). Data were subjected to analysis of variance and mean separation by Duncan's multiple range test (Statistical Analysis Systems, Cary, N.C. release 8.2 ).

\section{Results and Discussion}

Shoot dry weight of azalea was higher in $100 \%$ PB than in $100 \%$ PC or the $75 \%$ PC: $25 \%$ $\mathrm{PB}$ (Fig. 1). Shoot dry weight of marigold was higher for plants in 100\% PB and 75\% PC: $25 \%$ PB, than $100 \%$ PC. There was no difference

Table 1. Particle analysis of the three different container substrates used in this study.

\begin{tabular}{lrcc}
\hline $\begin{array}{l}\text { Particle size } \\
\text { range }(\mathrm{mm})\end{array}$ & $\begin{array}{r}\text { Pine } \\
\text { bark }\end{array}$ & $\begin{array}{c}\text { Pine } \\
\text { chips }\end{array}$ & $\begin{array}{c}75 \% \mathrm{PC} / \\
25 \% \mathrm{~PB}\end{array}$ \\
\hline$>12.5$ & $0.3^{\mathrm{z}}$ & 0 & 0 \\
6.3 & 9.2 & 0.4 & 2.7 \\
4.75 & 8.4 & 1.2 & 3.7 \\
2.36 & 28.8 & 56.0 & 49.5 \\
2 & 2.8 & 1.3 & 1.5 \\
1.4 & 9.6 & 9.4 & 8.9 \\
0.71 & 15.1 & 21.4 & 18.8 \\
0.5 & 6.2 & 3.5 & 4.7 \\
0.355 & 5.1 & 2.2 & 3.1 \\
0.25 & 4.0 & 1.5 & 2.3 \\
0.177 & 3.4 & 1.0 & 1.7 \\
0.125 & 1.8 & 0.5 & 0.9 \\
0.09 & 1.6 & 0.4 & 0.7 \\
0.063 & 1.1 & 0.2 & 0.4 \\
0 & 1.4 & 0.1 & 0.4 \\
\hline${ }^{z}$ Data represent means of three samples.
\end{tabular}


in shoot dry weight between the substrates for holly. While shoot dry weight for azalea and marigold was less in PC compared to PB, the overall visual quality of the plants grown in PC was acceptable. Root dry weight for holly was higher for $75 \%$ PC: $25 \%$ PB than $100 \%$ PB but not greater than $100 \%$ PC (Fig. 2). Visual observations of azalea and marigold root balls indicated that root growth in the PC was at least comparable to root growth for PB (data not shown).

Analysis of the substrate solution from fallow containers for PC and PB showed minor differences in $\mathrm{pH}$ and no difference in $\mathrm{EC}$ (Table 2). There were differences in levels of various nutrients but none that caused concern in terms of the suitability of pine chips as a container substrate. During the course of the study the substrate solution EC of the PC tended to be lower than that for PB. An attempt to maintain the substrate solution EC for the PC was made by providing weekly applications of fertilizer through the irrigation, but in some cases like azalea the EC was still lower for PC after 7 to 8 weeks (Table 3). This lower EC could partially account for the lower shoot dry weight for azalea grown in PC (Fig. 1). The lower EC of the PC could be due to PC retaining fewer nutrients than $\mathrm{PB}$ due to the lower CEC of PC compared to PB (Table 4). Also, the tendency for the $\mathrm{PC}$ to have lower EC could in part be due to more leaching of nutrients during irrigation due to the $\mathrm{PC}$ being more porous (to be discussed next).

The particle size analysis of the substrates revealed that the $\mathrm{PC}$ were coarser than $\mathrm{PB}$, having a much larger percent of the particles above $0.5 \mathrm{~mm}$ (Table 1). As well, the air space following irrigation and drainage was $40 \%$ for PC versus $15.6 \%$ for PB (Table 4). Container capacity (the gravimetric water present after irrigation and drainage), was not different between the three substrates. There was also no difference in the percent available water between PC and $\mathrm{PB}$, indicating that the water present in $\mathrm{PC}$ is equally available for plant use as with $\mathrm{PB}$. The amount of water available to the plant with PC could be increased considerably by increasing the amount of particles $0.5 \mathrm{~mm}$ and below, either by further grinding of the PC or adding a substrate such as finely ground peatmoss, compost, or finely ground PB to increase container capacity. This could be accomplished without compromising the percent air space which was at $40 \%$ for $\mathrm{PC}$ - well above an acceptable range of $15 \%$ to $25 \%$ - and without being a detriment to plant growth. Another favorable quality of PC observed during the course of this shortterm study was that no noticeable shrinkage of the substrate due to microbial decomposition occurred.

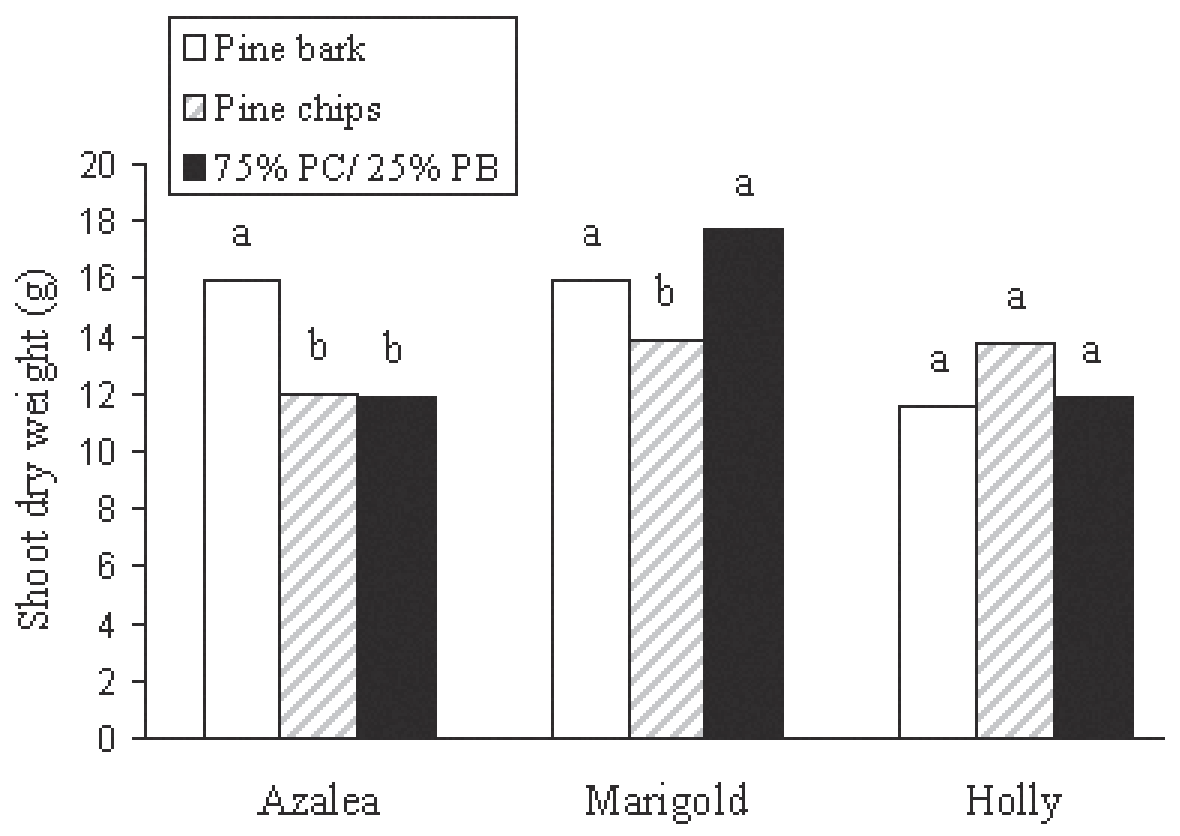

Fig. 1. Shoot dry weight of plants grown in three different substrates. Treatments with the same letter above bars within the same species are not different $(P<0.05)$; Duncan's multiple range test.

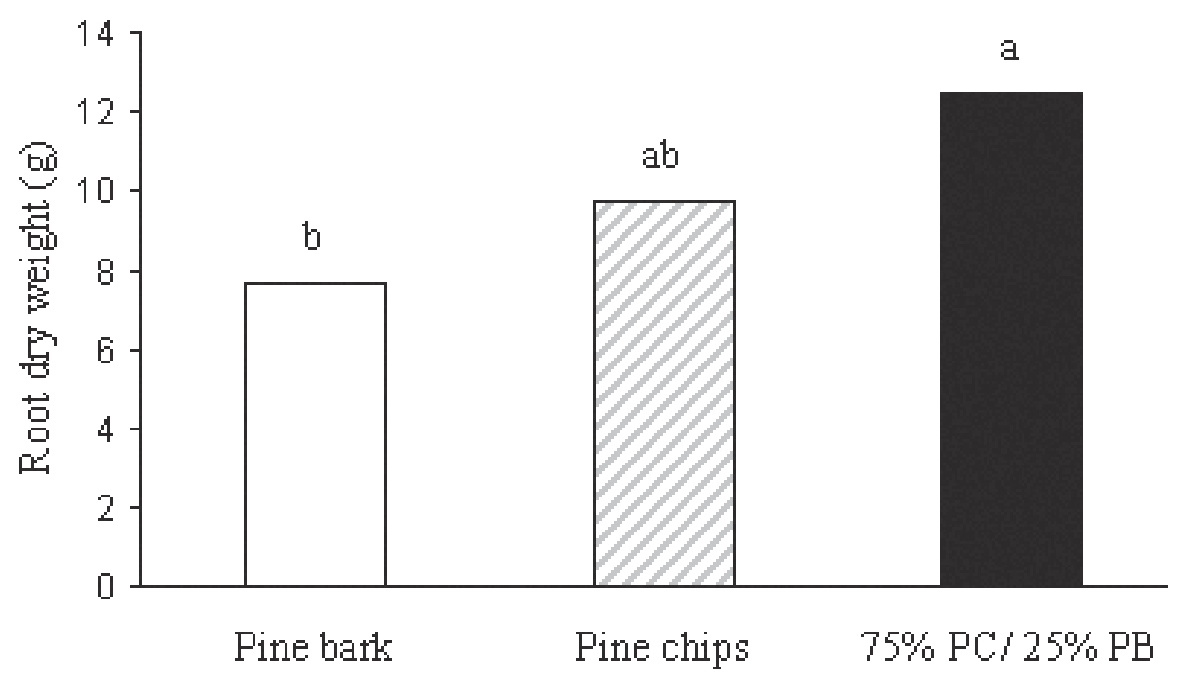

Fig. 2. Root dry weight of japanese holly grown in three different substrates. Treatments with the same letter above bars are not different $(P<0.05)$. Duncan's multiple range test.

\section{Conclusions}

Results from this study demonstrate the feasibility of growing greenhouse and nursery crops in a substrate with one component derived from whole pine logs. Because of different physical and chemical properties of PC compared to $\mathrm{PB}$ (porosity, water holding capacity and $\mathrm{CEC}$ ) different irrigation and nutritional management strategies may be necessary.

\section{Literature Cited}

Bugbee, G.J., C.R. Frink, and D. Migneault. 1991. Growth of perennials and leaching of heavy metals in media amended with a municipal leaf sewage sludge and street sand compost. J. Environ. Hort. 9:47-50.

Chong, C. and G.P. Lumis. 2000. Mixtures of paper mill sludge, wood chips, bark, and peat in substrates for pot-in-pot shade tree production. Plant Sci. 80:669-675.

Dueitt, S., J. Howell, and S.E. Newman. 1993. Rice

Table 2. Substrate solution pH, electrical conductivity (EC), and nutrient concentrations for pine bark and freshly ground pine chips on 14 Apr. 2004 before fertilization. Data represent means of six containers.

\begin{tabular}{lccccccccccccc}
\hline & & $\mathrm{EC}$ & \multicolumn{10}{c}{ Nutrient concn $\left(\mathrm{mg} \cdot \mathrm{L}^{-1}\right)$} \\
\cline { 5 - 13 } Substrate & $\mathrm{pH}$ & $\mathrm{dS} \cdot \mathrm{cm}^{-1}$ & $\mathrm{P}$ & $\mathrm{K}$ & $\mathrm{Ca}$ & $\mathrm{Mg}$ & $\mathrm{Cu}$ & $\mathrm{Fe}$ & $\mathrm{Mn}$ & $\mathrm{Zn}$ & $\mathrm{B}$ & $\mathrm{Mo}$ & $\mathrm{Al}$ \\
\hline Pine bark & $5.9 \mathrm{a}^{\mathrm{z}}$ & $0.11 \mathrm{a}$ & $0.6 \mathrm{~b}$ & $21.0 \mathrm{a}$ & $3.6 \mathrm{a}$ & $2.0 \mathrm{~b}$ & $0.003 \mathrm{a}$ & $0.07 \mathrm{~b}$ & $0.398 \mathrm{a}$ & $0.031 \mathrm{a}$ & $0.029 \mathrm{~b}$ & $0.005 \mathrm{a}$ & $0.12 \mathrm{~b}$ \\
Pine chips & $5.7 \mathrm{~b}$ & $0.09 \mathrm{a}$ & $2.7 \mathrm{a}$ & $17.3 \mathrm{a}$ & $3.5 \mathrm{a}$ & $3.0 \mathrm{a}$ & $0.004 \mathrm{a}$ & $0.12 \mathrm{a}$ & $0.004 \mathrm{~b}$ & $0.016 \mathrm{~b}$ & $0.049 \mathrm{a}$ & $0.006 \mathrm{a}$ & $0.31 \mathrm{a}$ \\
\hline
\end{tabular}

${ }^{2}$ Means were separated using Duncan's multiple range test $(P<0.05)$. Treatments with the same letters are not different. 
Table 3. Substrate solution $\mathrm{pH}$ and electrical conductivity (EC) for three species in three different container substrates on 1 June 2004. Data represent means of six containers.

\begin{tabular}{|c|c|c|c|c|c|c|}
\hline \multirow[b]{2}{*}{ Substrate } & \multicolumn{2}{|c|}{ Marigold } & \multicolumn{2}{|c|}{ Azalea } & \multicolumn{2}{|c|}{ Japanese holly } \\
\hline & $\mathrm{pH}$ & $\begin{array}{c}\mathrm{EC} \\
\left(\mathrm{dS} \cdot \mathrm{cm}^{-1}\right)\end{array}$ & $\mathrm{pH}$ & $\begin{array}{c}\mathrm{EC} \\
\left(\mathrm{dS} \cdot \mathrm{cm}^{-1}\right)\end{array}$ & $\mathrm{pH}$ & $\begin{array}{c}\mathrm{EC} \\
\left(\mathrm{dS} \cdot \mathrm{cm}^{-1}\right)\end{array}$ \\
\hline Pine bark & $4.9 \mathrm{a}^{\mathrm{z}}$ & $2.2 \mathrm{a}$ & $4.9 \mathrm{c}$ & $1.4 \mathrm{a}$ & $4.8 \mathrm{~b}$ & $1.6 \mathrm{a}$ \\
\hline Pine chips & $5.0 \mathrm{a}$ & $1.8 \mathrm{a}$ & $6.4 \mathrm{~b}$ & $0.5 \mathrm{~b}$ & $5.0 \mathrm{~b}$ & $1.6 \mathrm{a}$ \\
\hline $75 \% \mathrm{PC} / 25 \% \mathrm{~PB}$ & $4.9 \mathrm{a}$ & $2.3 \mathrm{a}$ & $6.6 \mathrm{a}$ & $0.5 \mathrm{~b}$ & $5.3 \mathrm{a}$ & $1.9 \mathrm{a}$ \\
\hline
\end{tabular}

${ }^{2}$ Means were separated using Duncan's multiple range test $(P<0.05)$. Treatments with the same letters are not different.

Table 4. Physical and hydraulic properties of three different container substrates. Data were collected from four containers per treatment and represented as means.

\begin{tabular}{|c|c|c|c|c|c|c|c|}
\hline Substrate & $\begin{array}{c}\text { Total } \\
\text { porosity }\end{array}$ & $\begin{array}{c}\text { Air } \\
\text { space }^{y}\end{array}$ & $\begin{array}{c}\text { Container } \\
\text { capacity }^{\mathrm{x}} \\
(\% \mathrm{vol})\end{array}$ & $\begin{array}{l}\text { Available } \\
\text { water }^{w}\end{array}$ & $\begin{array}{c}\text { Unavailable } \\
\text { water }^{v}\end{array}$ & $\begin{array}{c}\text { Bulk } \\
\text { density } \\
(\mathrm{g} / \mathrm{cc})\end{array}$ & $\begin{array}{c}\text { Cation } \\
\text { exchange } \\
\text { capacity } \\
\left(\mathrm{cmol} \cdot \mathrm{L}^{-1}\right)\end{array}$ \\
\hline Pine bark & $70 \mathrm{c}^{\mathrm{u}}$ & $15.6 \mathrm{c}$ & $54.4 \mathrm{a}$ & $27.9 \mathrm{a}$ & $26.6 \mathrm{a}$ & $0.25 \mathrm{a}$ & $18.8 \mathrm{a}$ \\
\hline Pine chips & $88.6 \mathrm{a}$ & $40 \mathrm{a}$ & $48.6 \mathrm{a}$ & $25.1 \mathrm{a}$ & $23.6 \mathrm{~b}$ & $0.16 \mathrm{~b}$ & $2.4 \mathrm{~b}$ \\
\hline $75 \% \mathrm{PC} / 25 \% \mathrm{~PB}$ & $82.8 \mathrm{~b}$ & $31.2 \mathrm{~b}$ & $51.6 \mathrm{a}$ & $26.6 \mathrm{a}$ & $25.0 \mathrm{ab}$ & $0.17 \mathrm{~b}$ & --- \\
\hline
\end{tabular}

${ }^{\mathrm{z}}$ Based on percent volume of $7.6 \times 7.6 \mathrm{~cm}$ core at $0 \mathrm{kPa}$.

yTotal porosity - container capacity.

${ }^{x}$ Measured as percent volume of a $7.6 \times 7.6 \mathrm{~cm}$ core at drainage.

${ }^{\mathrm{w}}$ Container capacity - unavailable water.

${ }^{\vee}$ Based on percent volume of a $7.6 \times 2.54-\mathrm{cm}$ core at $1500 \mathrm{kPa}$.

"Means were separated using Duncan's multiple range test $(P<0.05)$. hulls as a vermiculite substitute in peat-based media for growing greenhouse bedding plants. SNA Proc. 38:62-63.

Ehret, D.L., B.J. Zebarth, J. Portree, and T. Garland. 1998. Clay addition to soilless media promotes growth and yield of greenhouse crops. HortScience 33:67-70.

Kahtz,A.W. and N.J.Gawel. 2004. Growth of barberry liners in media amended with noncomposted recycled waste. HortTechnology 14:192-195.

Lunt, O.R. and B. Clark. 1959. Bark and wood fragments. Forest Prod. J. 9:39a-42a.

Owings, A.D. 1993. Cotton gin trash as a medium component in production of 'Golden Bedder' coleus. SNA Proceedings 38:65-66.

Pokorny, F.A. and H.Y. Wetzstein. 1984. Internal porosity, water availability, and root penetration of pine bark particles. HortScience 19:447-449.

Rosen, C.J., T.R. Halbach, and B.T. Swanson. 1993. Horticultural uses of municipal solid waste composts. HortTechnology 3:167-173.

Tyler, H.H., S.L. Warren, T.E. Bilderback, and W.C. Fonteno. 1993a. Composted turkey litter: I. Effect on chemical and physical properties of a pine bark substrate. J. Environ. Hort. 11:131-136.

Tyler, H.H., S.L. Warren, T.E. Bilderback, and K.B. Perry. 1993b. Composted turkey litter: II. Effect on plant growth. J. Environ. Hort. 11:137-141.

Wright, R.D. 1986. The pour-through nutrient extraction procedure. HortScience 21:227-229. 